\title{
LIVING SUNNAHTENTANG HIJRAH PARA ABITUREN NAHDHATUL WATHAN LOMBOK KE KOTABARU
}

\author{
M. Zainuddin Samima \\ Alumni Fakultas Ushuluddin dan Humaniora \\ IAIN Antasari Banjarmasin \\ Diterima tanggal 3 Januari 2016 / Disetujui tanggal 9 Maret 2016
}

\begin{abstract}
Prophet Mubammad, as the central figure in Islam, is an ideal model for Muslims so they compete to be as possible as similar to him in every ways. This deed can be called as living Sunnab. In the early days of Islam, he and his companions migrated (bijrah) from Makkah to Madinah to fulfill the order of Allah. Now, Muslims keep trying to imitate the Prophet's deed in the context of social, culture, politics, economics and others. One of them is the community of Abituren Nahdhatul Wathan Lombok, they tried to imitate Prophet's migration. They were out of hometown to migrate to Kotabaru with a mission to spread their organization's propaganda. Therefore, this work tries to determine their understanding of the tradition of Prophet's migration that initiate them to move to Kotabaru. This research is a field research, using three data collection techniques are observation, interviews and documentation. Then the nature of this study is qualitative, while the used approach is phenomenology to observe phenomena that occur in the community. In some conclusion, it can be said that the community of Abituren Nabdlatul Wathan Lombok understood the tradition of Prophet's migration in the way of Allah and His messenger as a move to goodness that is blessed by Allah and His Messenger as appropriate guidance. In the modern era, their migration to Kotabaru reflexed the form of jihad and the strong intention to spread Islamic vision in the new community in Kotabaru.
\end{abstract}

Kata kunci: Living Sunnah, hijrah, Abituren Nahdhatul Wathan Lombok.

\section{Pendahuluan}

Dalam kehidupan sehari-hari, figur Nabi Muhammad Saw. merupakan tokoh sentral dan teladan umat Islam di masanya dan di masa sesudahnya hingga akhir zaman. Walaupun sosoknya telah lama tiada, namun ajarannya selalu hidup dan dipegang teguh umatnya dari masa ke masa. Namun perubahan zaman dan perkembangan masyarakat yang semakin komplek sudah tak terelakkan, sementara umat Islam memiliki keinginan yang kuat untuk mengaplikasikan ajaran Islam dalam kehidupan sehari-hari sesuai dengan yang diajarkan oleh Nabi Muhammad meskipun dalam konteks ruang dan waktu yang berbeda. Adanya upaya aplikasi hadis dalam kehidupan sehari-hari inilah yang dapat disebut sebagai hadis yang hidup dalam masyarakat, atau istilah lazimnya adalah living hadis atau living sunnah. ${ }^{1}$

Ada beberapa varian living hadis atau living sunnah yaitu 1) tradisi lisan, misalnya pembacaan

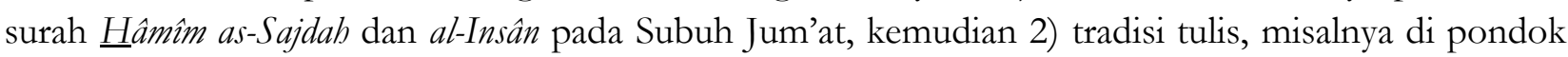
pesantren atau di sekolah-sekolah terdapat tulisan "an-naz̧hâfatu min al-îmân" (kebersihan itu sebagian dari iman), dan 3) tradisi praktik misalnya tradisi khitan perempuan. ${ }^{2}$ 
Salah satu living sunnah berbentuk tradisi praktik seperti yang dilakukan oleh beberapa abituren (alumni) Nahdhatul Wathan Lombok. Nahdhatul Wathan atau yang lazimnya disingkat NW merupakan salah satu organisasi kemasyarakatan Islam yang berasal dari Pulau Lombok, Nusa Tenggara Barat. Organisasi tersebut didirikan oleh putra daerah yang juga salah satu ulama kenamaan nusantara yaitu TG. KH. Zainuddin Abdul Majid. NW sendiri bergerak dalam ranah pendidikan, sosial, dan dakwah Islamiyah. Lebih khusus lagi sang pendiri telah meletakkan dasar pergerakan organisasinya dalam sebuah semboyan yang tersusun rapi, singkat, padat dan penuh makna yaitu "Pokoknya NW, Pokok NW Iman dan Taqwa". ${ }^{3}$

Sebagai bentuk kontribusinya, NW telah mendirikan ratusan sekolah dan pondok pesantren. Sampai awal tahun 2000 saja, sebagaimana yang dikutip oleh Dr. H. Masnun dalam disertasinya yang telah dibukukan, setidaknya ada 825 lembaga pendidikan NW yang tersebar di seluruh Indonesia. ${ }^{4} \mathrm{Di}$ Kalimantan Selatan sendiri, ada sekitar 4 lembaga pendidikan berbasis Nahdhatul Wathan yang salah satunya ada di Kabupaten Kotabaru. Penyebarannya sebagian besar dilakukan oleh para abituren atau alumni pondok pesantren NW itu sendiri, dengan cara hijrah dan menetap di berbagai daerah yang dituju. Mereka rela meninggalkan kampung halaman untuk hijrah atau pindah ke daerah lain dalam rangka melaksanakan tugas-tugas pokok NW yang berlandaskan iman dan taqwa.

Dalam Islam, hijrah adalah sesuatu yang sangat penting, mengingat hal tersebut pernah dilakukan oleh Nabi Muhammad Saw. Beliau hijrah atau pindah dari Makkah ke Madinah dalam rangka menyebarkan kalimat tauhid. Begitu pula hijrah yang dilakukan oleh para abituren NW, mereka hijrah atau pindah dari suatu tempat ke tempat lain dengan maksud menyebarkan iman dan taqwa. Dalam sebuah hadis Nabi Muhammad Saw. bersabda:

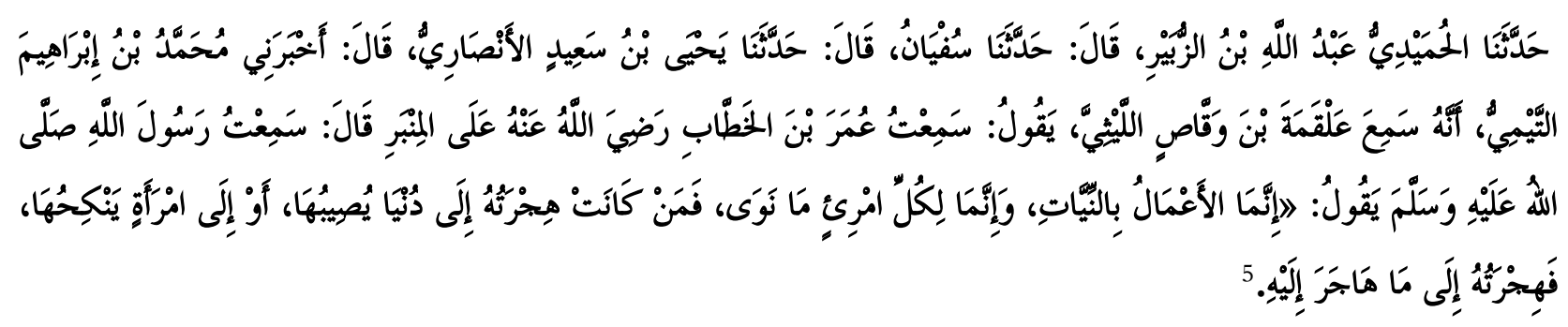

Pada hadis tersebut, Ibn Hajar al-Asqalânî (w. 852H) dalam kitab Fath al-Bârî memberikan penjelasan mengenai makna hijrah yaitu meninggalkan. Menurut syari'at, hijrah berarti meninggalkan apa yang dilarang oleh Allah Swt. Sedangkan di dalam Islam, hijrah memiliki dua pengertian yaitu pertama, hijrah berarti pindah dari tempat yang menakutkan ke tempat yang tenang. Kedua, hijrah berarti pindah dari negeri kafir ke negeri yang beriman. ${ }^{6}$

Berdasarkan data-data yang ditemukan di lapangan terkaitnya hijrahnya para abituren NW ke Kotabaru, tulisan ini mengkaji lebih jauh mengenai pemahaman mereka tentang hadis hijrah di atas, menjelaskan praktik hijrah yang mereka dilakukan, dan kontribusi hijrah tersebut bagi masyarakat setempat. Data diambil melalui riset lapangan dengan metode wawancara terhadap para responden yang merupakan pelaku langsung dari praktik ini.

${ }^{3}$ Muslihan Habib dan Thaharuddin, Nilai-nilai Monumental dalam Semboyan NW (Jakarta: Penerbit Pondok Pesantren NW, 2013), xvii-xxi.

${ }^{4}$ Masnun, Tuan Guru K.H. Zainuddin Abdul Majid: Gagasan dan Gerakan Pembaharuan Islam di Nusa Tenggara Barat (Jakarta: Pustaka al-Miqdad, 2007), 65-72.

${ }^{5}$ Muhammad Ibn Ismâ'îl Abû 'Abdullâh al-Bukhârî, Shabîh al-Bukhârî, Vol. 1 (T.tp: Dâr Thauq al-Najâh, 1422 H), 6.

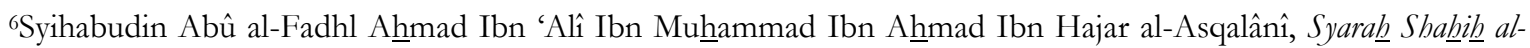
Bukhârî, Terj. Gazirah Abdi Ummah, Vol. 1 (Jakarta: Pustaka Azzam, 2002), 26. 


\section{Mengenal Kotabaru: Setting Hijrah Abituren Nahdhatul Wathan}

Kabupaten yang terkenal dengan gunung bamega ini terletak di sebelah Tenggara Provinsi

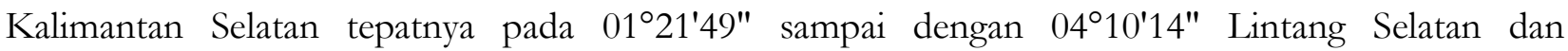

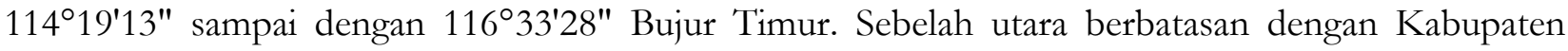
Paser Kalimantan Timur, sebelah selatan berbatasan dengan laut Jawa, sebelah timur berbatasan dengan selat Makasar, dan sebelah barat berbatasan dengan Kabupaten Hulu Sungai Selatan, Hulu Sungai Tengah, Banjar, dan Tanah Bumbu. ${ }^{7}$

Luas wilayah kabupaten Kotabaru sekitar 9.442,46 km2. Dengan luas wilayah tersebut, kabupaten Kotabaru merupakan kabupaten terluas di Propinsi Kalimantan Selatan dengan lebih dari seperempat $(25,11 \%)$ dari luas wilayah Propinsi Kalimantan Selatan. Akan tetapi, jumlah penduduk di Kabupaten Kotabaru tidak berbanding lurus dengan luas wilayahnya sebagai kabupaten terluas di Kalimantan Selatan. Jumlah penduduk Kotabaru sampai tahun 2014 sejumlah 314.492 jiwa. Jumlah tersebut menduduki posisi kelima dari 13 kabupaten yang ada di Kalimantan Selatan. ${ }^{8}$

Potensi daerah Kabupaten Kotabaru meliputi sektor kehutanan, pertambangan, perikanan dan pariwisata. Sektor Kehutanan, misalnya, hutan bagi Kabupaten Kotabaru mempunyai posisi yang cukup penting dalam percaturan ekonomi wilayah ini. Selain merupakan sumber pendapatan daerah, kehutanan juga mampu menyerap tenaga kerja yang cukup besar. Kemudian dalam sektor pertambangan, Kabupaten Kotabaru memiliki berbagai jenis bahan tambang seperti batubara, batu kapur, batu gunung.

Adapun dari sektor perikanan, Kabupaten Kotabaru memiliki potensi perairan yang cukup besar dengan luas laut mencapai $38.490 \mathrm{~km} 2$ dan panjang pesisir pantai $825 \mathrm{~km}$. Usaha penangkapan ikan merupakan mata pencaharian utama sebagian besar penduduk dengan produksi mencapai 44.898 ton (2005). Selain itu ada pula usaha budidaya di perairan payau (tambak udang/bandeng), budidaya di air tawar (kolam ikan mas, nila), budidaya di laut seperti rumput laut dan jaring apung (ikan kerapu) serta dimulainya budidaya tiram mutiara.

Selanjutnya sektor yang paling menarik minat pengunjung untuk datang ke Kotabaru adalah pariwisata. Kabupaten Kotabaru mempunyai potensi yang besar, berupa potensi wisata pantai, sumber air panas, goa, wisata bahari, gunung. Dari potensi wisata tersebut wisata alam dapat berupa pantai (Sarang tiung, Gedambaan, Tanjung Pemancingan), sumber air panas, penyu bertelur, (di pulau Birah-birah), Pulau Manti (memiliki pasir putih dan air yang jernih), Goa (Sugung, Tamuluang, Batu batulis, Tangkinang). Wisata budaya yang ada di Kabupaten ini adalah Lomba perahu katir (Pulau Laut Selatan), acara adat maceratasi (Pantai Sarangtiung), dan acara adat Babalian Dewa (hampang).

${ }^{7}$ Badan Perencanaan Pembangunan daerah Kotabaru, "Geografis Kotabaru", dalam http://www.bappedakotabaru.info/umum/80/, diakses pada 6 Mei 2016.

8Badan Pusat Statistik, dalam http://kalsel.bps.go.id/linkTableDinamis/view/id/813, diakses pada 6 Mei 2016.

'Info Kalsel, "Kabupaten Kotabaru” dalam http://infokalsel.blogspot.co.id/2011/04/kabupaten-kotabaru.html, diakses 6 Mei 2016. 


\section{Para Abituren Nahdhatul Wathan Memahami Hadis-Hadis Hijrah}

\section{Redaksi Hadis}

a. Hadis Hijrah di Jalan Allah dan Rasul-Nya

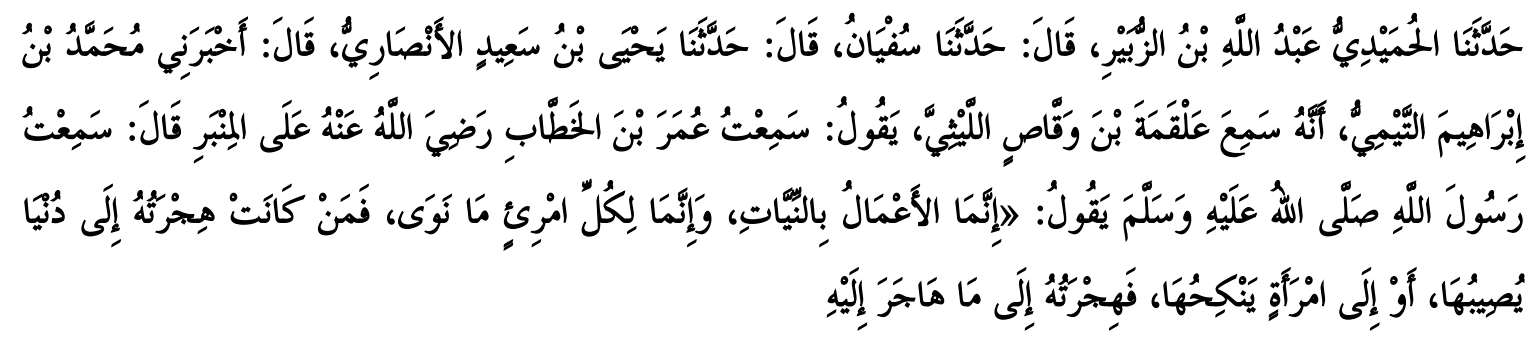

Hadis tersebut diriwayatkan oleh Imam al-Bukhari (w. $256 \mathrm{H}$ ) yang merupakan hadis pertama dan di letakkan pada bab pertama dalam al-Jâmi' ash-Shahbîh, karyanya. Imam alBukhari juga meriwayatkan dengan lafal yang sedikit berbeda, tetapi maknanya tetap sama, yaitu:

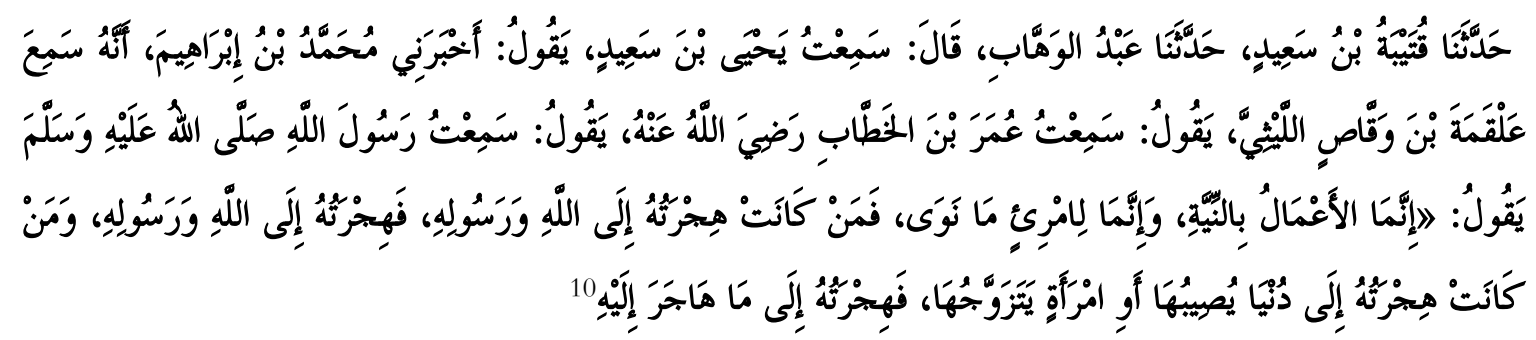

Letak perbedaannya terdapat pada kata niat, riwayat yang pertama menggunakan bentuk jama' (plural) sementara riwayat yang kedua menggunakan bentuk mufrad (tunggal). Demikian pula pada kata menikahi, riwayat pertama menggunakan lafal yankiȟubâ sementara yang kedua yatazawwajuhâ.

Hadis ini juga diriwayatkan oleh Imam Muslim (w. $261 \mathrm{H}$ ) pada kitab al-Imârah bab Qaulubûu Innamâ al-A'mâl bi an-Niyyât dengan lafal yang sama dengan riwayat yang kedua tadi. ${ }^{11}$ Juga diriwayatkan oleh at-Tirmîdzî (w. 279 H) pada sunannya kitab Fadhẩil al-Jihâd 'an Rasûlillâh dengan lafal sama dengan Muslim. ${ }^{12}$ Sementara Abû Dâwud (w. 275 H) dalam sunannya kitab ath-Thalâq bab Fî̀ Mâ'Uniya Bibi ath-Thalâq wa an-Niyyât dengan lafal niat dalam bentuk jama' dan kata yatazamwajuba.$^{13}$ Imam an-Nasa'î (w. $303 \mathrm{H}$ ) pun meriwayatkan dalam

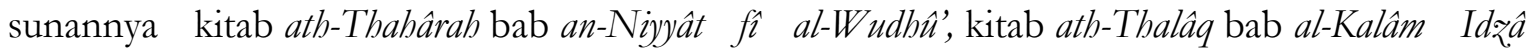
Qashuda Bibi Fî Mâ Yubtamalu Ma'nabu dan kitab al-Aimân wa an-Nudžûr bab an-Niyyât fì alYamin dengan lafal yang sama dengan riwayat al-Bukhari yang kedua di atas. ${ }^{14}$ Kemudian juga Imam Ibnu Mâjah (w. $273 \mathrm{H}$ ) meriwayatkan dalam sunannya kitab ą-Zubd bab an-Niyyât. ${ }^{15}$ Demikian pula dengan Imam A $\underline{h}$ mad (w. $241 \mathrm{H}$ ), ia meriwayatkan dalam musnadnya pada bab Awwal Musnad Umar Ibn Khaththâb dengan lafal niat mufrad namun kata menikah H), 140.

${ }^{10}$ Abû 'Abdullâh Muhammad Ibn Ismâ’îl al-Bukhârî, Shahîh al-Bukhârî, Vol. 8 (T.tp: Dâr Thauq al-Najâh, 1422 1996), 59.

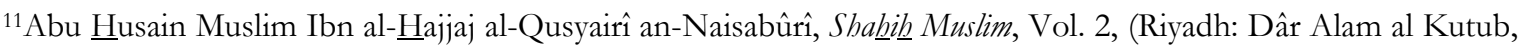

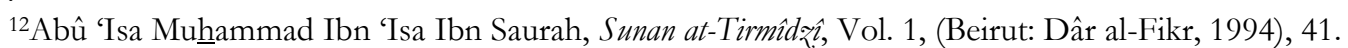

${ }^{13}$ Abû Dâwud Sulaimân Ibn Asy’ats as-Sijistâni, Sunan Abû Dâwud, Vol. 1, (Suriah: Dâr al-Hadîts, t.th), 69.

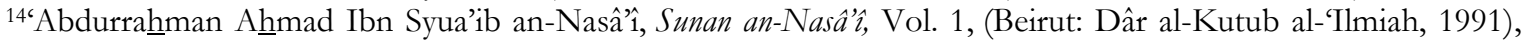
15. t.th), 1413 .

${ }^{15}$ Abû 'Abdullâh Ibn Yazid Ibn Mâjah al-Qazwînî, Sunan Ibn Mâjah, Vol. 2, (t.tp: Dâr Ihya al-Kutb al-'Arabiyyah, 
menggunakan yankihâhba ${ }^{16}$ Kemudian mengenai kualitasnya, hadis di atas diriwayatkan oleh para râmı̂ yang tsiqah dan bersambung sampai ke Nabi. Di sisi lain, mengingat al-Bukhari sebagai mukhârij hadis yang sangat teliti meletakkannya dalam kumpulan hadis shab̂îh maka keshahihan hadis tersebut dapat dipercaya. Ditambah lagi hadis diatas juga dinilai shab $\underline{i b}$ oleh al-Albânî (w. $1420 \mathrm{H}) \cdot{ }^{17}$

b. Hadis Tidak Ada Hijrah Setelah Fath Makkah

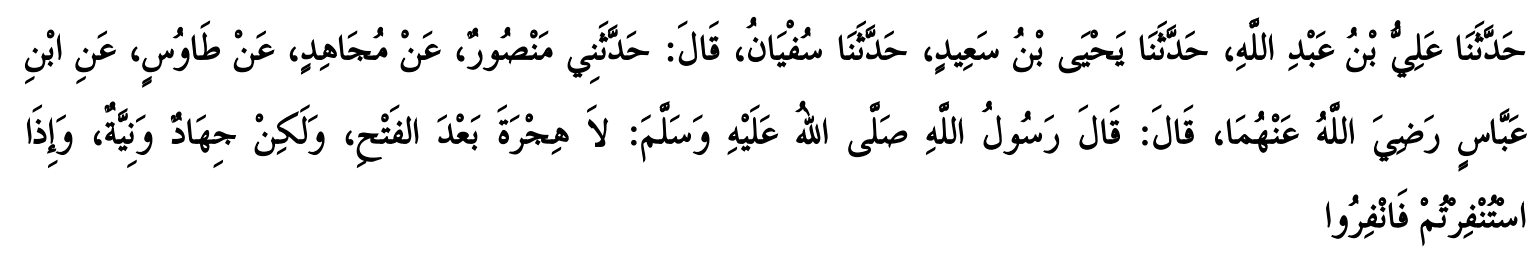

Hadis tersebut diriwayatkan oleh Imam al-Bukhari (w. $256 \mathrm{H}$ ) dalam al-Jâmi' ash-Shabîth karyanya pada bab Fadhl al-Jihâd wa as-Siri melalui jalur sahabat Ibn 'Abbas. ${ }^{18}$ Keberadaan

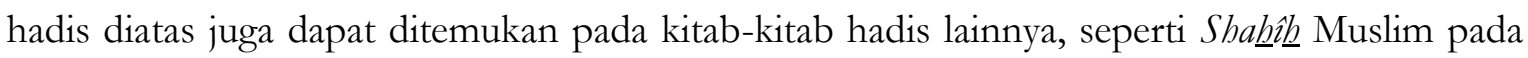
bab al-Mubâya'ah Ba'da Fath Makkah 'ala al-Islâm', Sunan at-Tirmîdzî pada bab Mâ Jâ'a Fî alHijrah, ${ }^{20}$ Musnad Ahmad pada musnad 'Abdullâh Ibn 'Abbas Ibn 'Abd al-Mutbthalib. ${ }^{21}$ Kemudian mengenai kualitasnya, kesahihannya dapat dipercaya karena semua râm $̂$ yang meriwayatkan hadis diatas memiliki kredibilitas yang tinggi dengan predikat tsiqah, ditambah lagi hadis

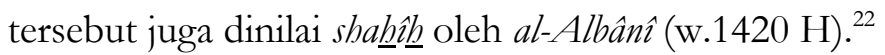

\section{Pemahaman Para Abituren NW tentang Hadis Hijrah di Jalan Allah dan Rasul-Nya dan Hadis Tidak Ada Hijrah Setelah Fath Makkah}

Berikut adalah pemaparan tentang pemahaman para abituren NW masing-masing tentang hadis hijrah di jalan Allah dan Rasul-Nya dan hadis tidak ada hijrah setelah fath Makkah:

a. Responden I

Menurut responden I, yang dimaksud hijrah dalam hadis pertama adalah hijrah tidak hanya berpindah secara fisik dari suatu tempat ke tempat lain, tetapi juga memiliki makna hijrah dari perbuatan buruk ke perbuatan yang baik. Oleh sebab itu, hijrah yang dilakukan oleh para abituren NW ke berbagai tempat mencakup kedua makna hadis tersebut. Misalnya mereka hijrah ke Kalimantan, secara fisik mereka meninggalkan kampung halaman yakni pulau Lombok kemudian menetap di Kalimantan. Di tempat yang baru, mereka mengemban amanah untuk menyebarkan visi-misi NW yakni iman dan taqwa melalui pendidikan, sosial dan dakwah, hal itu bertujuan untuk merubah akhlaq atau perilaku masyarakat yang kurang baik menuju akhlaq yang lebih baik sesuai dengan ajaran Islam. ${ }^{23}$

Adapun tentang hadis kedua bahwa tidak ada hijrah setelah fath Makkah, responden I berpandangan bahwa tidak ada hjrah seperti yang dilakukan Nabi, tidak ada problematika dan

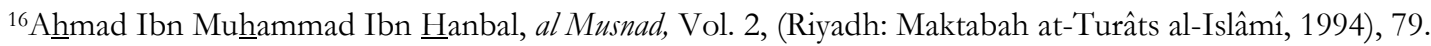

${ }^{17}$ Abû Dâwud, Sunan Abû Dâwud, Vol. 2, 262.

${ }^{18} \mathrm{Al}-\mathrm{Bukhâr} \hat{1}$, Shahîh $\underline{\underline{h}}$ al-Bukhârî, Vol. 4, 15.

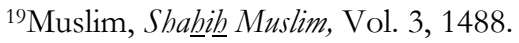

${ }^{20}$ At-Tirmîdzî, Sunan at-Tirmîdzî, Vol. 3, 148.

${ }^{21} \mathrm{Ah}$ mad, al Musnad, Vol. 3, 448.

${ }^{22}$ At-Tirmîdzî, Sunan at-Tirmîdž̂, Vol. 3, 148.

23Pimpinan Pondok Pesantren Nurun Nahdhatain Kotabaru, Wawancara Pribadi, Kotabaru, 01 April 2016. 
gejolak seperti pada zaman Nabi, yang mana para muhajirin meninggalkan istri, harta benda, dan jabatan pada saat hijrah. Akan tetapi, hijrah umat Islam pada masa selanjutnya adalah dengan jihad atau perjuangan dan dengan niat. Oleh sebab itu, hijrah akan selalu ada hingga ahir zaman. ${ }^{24}$ Lebih lanjut, beliau menjelaskan tentang sebab-sebab seseorang melakukan hijrah itu ada tiga, yaitu hijrah untuk menyelamatkan agama, hijrah untuk mencari suasana agama, dan hijrah untuk bertaubat.

\section{b. Responden II}

Responden ini menyatakan bahwa yang dimaksud hijrah di dalam hadis pertama adalah hijrah untuk mencari Allah dan Rasul-Nya yaitu untu kebaikan, hijrah bukan untuk urusan dunia. Sebagaimana yang dilakukan oleh para abituren NW yang hijrah untuk menyebarkan cita-cita NW yaitu iman dan taqwa. Setelah melakukan hijrah kepada kebaikan maka dunia akan mengikuti nantinya. ${ }^{25}$

Sementara maksud hadis yang kedua, tidak ada hijrah setelah fath Makkah adalah tidak ada hijrah seperti yang lakukan Rasulullah, untuk menghindari musuh yakni kafir Quraisy. Akan tetapi, hijrah pada masa kini adalah hijrah dengan jihad, hijrah dari keburukan kepada kebaikan. Hijrah yang merupakan sebuah perjuangan atau jihad harus disertai niat. Dengan kata lain, tidak disebut berjihad jika tidak disertai niat. Sebagaimana yang dilakukan para abituren NW yang melakukan hijrah dengan niat untuk dakwah, sehingga jika para abituren yang hijrah tidak dengan niat dakwah seperti yang disebut diatas, maka ia tidak termasuk dalam kategori hijrah yang dimaksud. ${ }^{26}$

\section{c. Responden III}

Menurut responden ketiga ini, hijrah sebagaimana yang dimaksud hadis pertama adalah hiijrah untuk kebaikan, karena hadis itu diawali dengan masalah niat, maka hijrah yang dilakukan harus dengan niat yang baik. Tujuan niatnya pun untuk kebaikan bukan untuk tujuan-tujuan terkait urusan dunia. ${ }^{27}$

Sementara maksud hadis yang kedua tentang tidak ada hijrah setelah fath Makkah adalah tidak ada hijrah seperti yang dilakukan sebelumnya, karena pada saat itu Islam telah merebut kekuasaan maka tidak perlu lagi hijrah dalam rangka mencari tempat yang aman. Akan tetapi hijrah setelah itu adalah dengan jihad atau perjuangan. Hadis tersebut juga terkait dengan niat maka untuk berjihad butuh niat yang mantap, sehingga akan kuat menghadapi segala cobaan dan rintangan. ${ }^{28}$

\section{d. Responden IV}

Adapun responden keempat menjelaskan bahwa maksud hadis hijrah pertama adalah hijrah ke jalan yang diridhai oleh Allah dan Rasul-Nya, dalam artian sesuai dengan tuntunan yang diajarkan Nabi Saw., bukan hijrah untuk urusan dunia. Hal itu lah yang dilakukan oleh para abituren NW yang hijrah dengan membawa amanah dari masyaikh untuk menyebarkan pokok NW yakni iman dan taqwa ke seluruh penjuru alam. Bisa dipastikan para abituren yang hijrah ke berbagai tempat itu dengan niat baik seperti yang disebutkan tadi, bukan urusan dunia seperti faktor ekonomi yang menjadi tujuan utama. Adapun usaha-usaha dunia yang dilakukan

\footnotetext{
${ }^{24}$ Pimpinan Pondok Pesantren Nurun Nahdhatain Kotabaru, Wawancara Pribadi, Kotabaru, 01 April 2016.

25Pimpinan Majelis Ta'lim al-Muttaqin Bandar Raya, Wawancara Pribadi, Kotabaru, 01 April 2016.

26Pimpinan Majelis Ta’lim al-Muttaqin Bandar Raya, Wawancara Pribadi, Kotabaru, 01 April 2016.

${ }^{27}$ Guru TK, Wawancara Pribadi, Kotabaru, 04 April 2016.

${ }^{28}$ Guru TK, Wawancara Pribadi, Kotabaru, 04 April 2016.
} 
untuk menunjang kehidupan, dan tetap dakwah sebagai tujuan utama. Hal ini bisa dipastikan karena dari pusat NW di lombok selalu mengamati para utusannya. ${ }^{29}$

Adapun makna yang terkandung dalam hadis kedua adalah tidak ada hijrah setelah ini seperti hijrah pada saat sebelum fath Makkah. Akan tetapi hijrahnya adalah dengan jihad atau perjuangan, karena jihad yang paling besar adalah melawan hawa nafsu. Oleh sebab itu, hijrahnya adalah dari sifat-sifat buruk kepada pribadi yang baik. ${ }^{30}$

Setelah memaparkan pemahaman masing-masing para abituren NW Lombok yang hijrah ke Kotabaru tentang hadis hijrah di jalan Allah dan Rasul-Nya dan hadis tidak ada hijrah setelah fath Makkah, maka dapat dilihat bahwa pemahaman mereka tentang hadis-hadis tersebut tidak tekstual atau membaca hadis semata-mata berdasarkan bunyi teks. Lebih dari itu, mereka memahami hadis dengan mempertimbangkan bagaimana konteks hadis. Sejauh ini, pemahaman mereka sejalan atau memiliki maksud yang sama. Jika ditarik garis lurus, maka hijrah memiliki dua makna, yaitu hijrah secara fisik dan hijrah non fisik. Hijrah secara fisik berarti pindah tempat yaitu seseorang pindah dari suatu tempat ke tempat yang lain, dengan niat dan tujuan mengharap ridha Allah Swt. kemudian hijrah secara non fisik adalah hijrah dari perilaku yang buruk kepada perilaku yang baik.

Adapun terkait dengan hadis tidak ada hijrah setelah fath Makkah, dari pemahaman yang mereka berikan jelas terlihat bahwa pemahaman mereka tentang hadis tersebut melihat konteks hadisnya. Tidak ada hijrah artinya tidak ada hijrah seperti yang dilakukan oleh Nabi dan para Sahabatnya sebelum fath Makkah, akan tetapi hijrah setelah itu adalah dengan jihad dan niat. Hal ini juga sejalan dengan pendapat Dr. Abdullah Azzam yang mengatakan tidak ada hijrah yang dimaksud adalah hijrah dari Makkah ke Madinah, karena telah terputus setelah ditaklukkannya kota Makkah pada tahun ke 8 Hijriyah. Maka berakhir pula pahala hijrah yang semula diperhitungkan. Mereka yang berhijrah sebelum fath Makkah mendapat kehormatan dan gelar yakni para mubäjirîn, namun setelah fath Makkah mereka yang melakukan hijrah tidak lagi mendapatkan kehormatan tersebut. Sebagai penggantinya adalah dengan jalan jihad dan jalan niat untuk berjihad untuk meraih pahala hijrah tersebut. Dengan begitu, hijrah akan terus berlangsung hingga akhir zaman. ${ }^{31}$

Pada hakikatnya, hijrah akan selalu ada dan terus berkembang di setiap masa dan tempat. Hijrah akan terus berlangsung selama ada pertentangan antara yang haq dan yang bathil. Peristiwa hijrah pertama kali diakukan oleh Nabi Adam As. ke dunia. Walaupun secara lahiriah hijrah yang beliau lakukan berbeda dengan yang dilakukan oleh keturunan beliau selanjutnya yang terdiri dari para nabi dan rasul, namun secara esensial hijrah yang dilakukan Nabi Adam As. memiliki kesamaan yaitu sama-sama disebabkan oleh simbol kebathilan. Para Rasul terusir dari rumah mereka dikarenakan orang-orang musyrik sedangkan penyebab terusirnya Nabi Adam As. dari surga adalah Iblis sebagai lambang kekufuran.

Pada masa selanjutnya, hijrah dilakukan oleh Nabi Nuh As. dengan para pengikutnya dari dataran rendah ke yang lebih tinggi dan kemudian Allah Swt. menyelamatkan orang-orang yang berhijrah. Kemudian Nabi Ibrahim As. bersama putranya Ismail dan isterinya Hajar, hijrah dari Irak ke Syam, Mesir, dan ke Jazirah Arab. Selanjutnya Musa As. hijrah bersama para pengikutnya. Beberapa contoh diatas menandakan bahwa hijrah telah berlangsung sejak zaman dahulu. ${ }^{32}$

Begitu pula pada masa kini, hijrah masih terus berlangsung. Seperti yang dilakukan oleh para abituren atau alumni pondok pesantren NW Lombok, mereka hijrah ke berbagai wilayah, keluar dari

\footnotetext{
${ }^{29}$ Kepala Sekolah MTs Nurun Nahdhatain, Wawancara Pribadi, Kotabaru, 04 April 2016.

${ }^{30}$ Kepala Sekolah MTs Nurun Nahdhatain, Wawancara Pribadi, Kotabaru, 04 April 2016.

${ }^{31}$ Abdullah Azzam, Hijrah dan I'dad, terj. Abdurrahman (Solo: Pustaka al-Alaq, 2001), 145-146

${ }^{32}$ Muhammad 'Abdullah al-Khatib, Makna Hijrah Dulu dan Sekarang, terj. Abdul Mu'in HS dan Misbahul Huda (Jakarta: Gema Insani Press, 2002), 64-81
} 
kampung halaman untuk menyebarkan iman dan taqwa. Hal ini menurut Responden I adalah sebagai bentuk meneladani Rasulullah Saw.

\section{Praktik Hijrah Para Abituren Nahdhatul Wathan Lombok Ke Kotabaru}

\section{Latar Belakang Hijrah Para Abituren Nahdhatul Wathon Lombok ke Kotabaru}

Di kalangan abituren atau alumni Nahdhatul Wathan, hijrah atau berpindah dari suatu tempat ke tempat lain menjadi sebuah tradisi dan hingga kini masih dilestarikan. Hijrah yang mereka lakukan dalam rangka menyebarkan panji-panji Nahdhatul Wathan. Hal ini sering disampaikan oleh Sang pendiri dalam berbagai kesempatan, dan di dalam kitab Hizib Nahdhatul Wathan banyak tertuang kalimat yang mengatakan; وانشر لواء فضة الوطن في العالمين (sebarluaskanlah panji-panji Nahdhatul Wathan ke seluruh dunia).

Dalam rangka menyebarluaskan panji-panjinya, NW tentu memiliki tujuan dan ruang lingkup pergerakannya. NW sebagai organisasi profesional sejak berdirinya telah memiliki tujuan yang jelas dan terarah. Adapun tujuannya sebagaimana yang tercantum dalam AD/ART organisasi ini adalah $L i$ I'lâi Kalimâtillâh wa Tzza al-Islâm wa al-Muslimîn. Kemudian, untuk mencapai tujuan tersebut maka ditetapkan ruang lingkup kegiatan atau pergerakannya adalah bergerak di bidang pendidikan, sosial, dan dakwah Islamiyah.

Lebih lanjut, tradisi hijrah di kalangan abituren NW kongkritnya dapat dilihat ketika bulan ramadhan. Para santri dikirim ke berbagai daerah di pulau Lombok dan sekitarnya, para abituren atau santri yang dianggap mumpuni dikirim ke luar pulau Lombok, seperti Sulawesi, Kalimantan, Sumatera, dan lain sebagainya. Kegiatan tersebut lebih familiar disebut dengan safari Ramadhan.

Responden II, yang notabenenya seorang abituren NW sejati mengungkapkan bahwa tradisi hijrah yang dilakukan adalah dalam rangka mengamalkan ketaqwaan kepada Allah Swt., sebagaimana Allah Swt. berfirman dalam Q.S. al-Jumu'ah/62: 10.

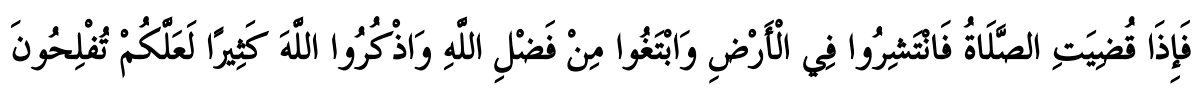

Pada ayat ini, Allah Swt. menyeru kepada hamba-Nya untuk bertebaran atau menyebar di muka bumi. Tujuannya adalah untuk mendapatkan karunia dari-Nya. Kemudian, ayat yang lain, yang menjadi dasar hijrahnya adalah Q.S. al-Baqarah/2: 218.

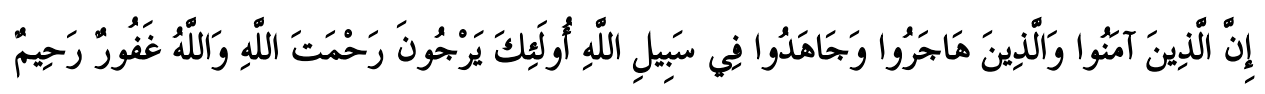

Allah Swt. mensejajarkan antara orang-orang yang beriman, berhijrah, dan berjihad di jalan Allah bahwa mereka adalah golongan orang-orang yang mengharapkan rahmat dari Allah Swt., kemudian Q.S. al-'Ashr/103: 3.

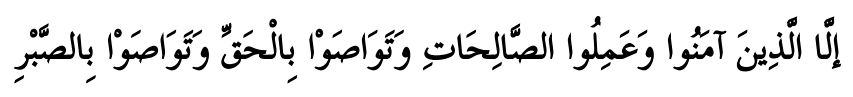

Dari ayat tersebut, Allah Swt. memberitahukan bahwa salah satu yang termasuk orang-orang yang beruntung menurut Allah adalah orang yang menyeru kepada kebaikan dan sabar.

Menurut peneliti, pada dasarnya, hijrah yang dilakukan oleh para abituren NW ke berbagai tempat yang salah satunya dilakukan ke Kotabaru, adalah bentuk kongkrit atau aktualisasi dari Ayatayat yang disebutkan diatas. Pada Q.S. al-Jumu'ah/62: 10, Allah Swt. menyeru untuk menyebar di bumi milik-Nya, maka para abituren NW dikirim ke berbagai wilayah dengan membawa misi dakwah, bukan sekedar berkelana atau istilah lazimnya merantau. 
Pada Q.S. al-Baqarah/2: 218, Allah menginformasikan keutamaan orang-orang berhijrah sejajar dengan orang yang beriman dan berjihad. Maka pada dasarnya para abituren NW melakukan ketiga bentuk keutamaan tersebut. Mereka melakukan jihad atau berjuang di jalan Allah dengan cara hijrah ke berbagai tempat untuk dakwah, itu semua membutuhkan kadar keimanan yang tinggi. Karena di dalam jihad yang dilakukan tersebut, mereka menghadapi berbagai macam cobaan dan rintangan yang akan menggoyahkan keyakinan mereka. Dengan demikian, ketiga hal tersebut, keimanan, hijrah dan jihad adalah satu kesatuan yang tidak bisa dipisahkan.

Kemudian pada QS. al-'Ashr/103: 3, Allah memerintahkan untuk menyeru kepada kebaikan dan sabar. Justru itulah yang dilakukan oleh para abituren NW di dalam hijrah yang dilakukan tersebut, dalam dakwah tentu mengajak kepada kebaikan. Tidak disebut dakwah Islamiyah jika yang diseru adalah kepada hal-hal yang tidak baik.

Adapun titik temu dari ketiga ayat yang disebutkan di atas adalah hijrah kepada kebaikan, yakni hijrah untuk amar ma'ruf dan nahi munkar atau melakukan hal-hal yang diridhai oleh Allah Swt. serta sesuai dengan Sunnah Rasul Saw. Hal ini diperkuat dengan hadis Nabi berikut:

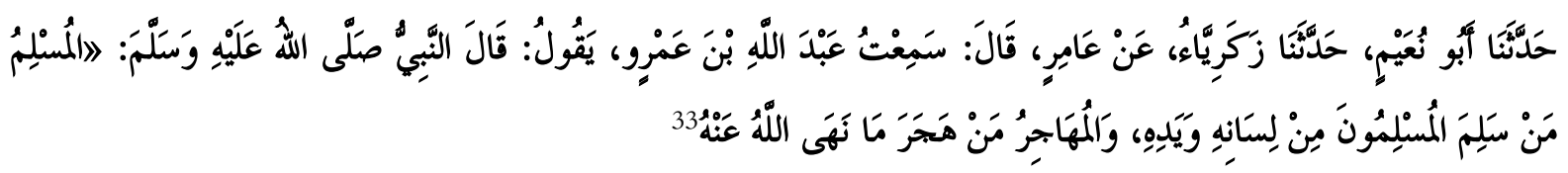

Dalam hadis tersebut dikatakan bahwa orang yang berhijrah adalah orang yang menjauhkan dirinya dari apa yang dilarang oleh Allah Swt. Dengan kata lain, orang yang berhijrah adalah orang yang melakukan hal-hal yang diridhai Allah, dan menjauhi apa yang dilarang. Oleh sebab itu, hijrah yang dilakukan oleh para abituren NW ke berbagai tempat dengan keimanan yang kuat membawa misi dakwah, untuk berjuang di jalan Allah Swt. adalah termasuk dalam kandungan hadis hijrah di jalan Allah dan Rasul-Nya.

\section{Proses Hijrah Para Abituren Nahdhatul Wathan Lombok Ke Kotabaru}

Untuk mengetahui tentang proses hijrah para abituren NW, maka perlu dipaparkan mengenai proses kedatangan masing-masing abituren NW ke Kotabaru.

a. Responden I

Pada mulanya, kedatangan responden I ke Kotabaru karena ada program Safari Ramadhan ke Kalimantan. Pada tahun 2003, tepat seminggu sebelum bulan Ramadhan, beliau diutus untuk melakukan safari Ramadhan ke Kotabaru bersama empat orang lainnya, yaitu Ustadz NR, Ustadz IZ, Ustadz MH, dan responden IV. Adapun pemilihan tempat yang dituju berdasarkan permintaan, yaitu pihak dari simpatisan NW di Kotabaru meminta untuk didatangkan ustadz ke tempat mereka khususnya masyarakat Desa Subur Makmur Kecamatan Pulau Laut Barat.

Kedatangan beliau kedua kalinya pada tahun 2004 sebagai petunjuk jalan, juga dalam rangka safari Ramadhan bersama empat orang lainnya yakni responden II, Ustadz FJ, Ustadz AY, dan Ustadz HZ. Kemudian kedatangan beliau yang ketiga kalinya pada tahun 2005 adalah awal mula memutuskan untuk hijrah ke Kotabaru dalam rangka melakukan dakwah sesuai dengan cita-cita Nahdhatul Wathan. 
b. Responden II

Awal kedatangan responden II ke Kotabaru pada tahun 2004, bersama responden I dalam rangka safari Ramadhan. Kedatangan beliau kali ini juga berdasarkan permintaan dari masyarakat setempat. Kemudian pada tahun 2005, pada kedatangan kedua, beliau memutuskan untuk hijrah ke Kotabaru dengan niat dan tujuan yang sama, yakni melakukan misi dakwah sesuai dengan cita-cita Nahdhatul Wathan.

c. Responden III

Berbeda dengan yang lainnya, responden III adalah satu-satunya abituren wanita yang hijrah ke Kotabaru. Kedatangan beliau pertama kali pada tahun 2005 dan langsung memutuskan untuk hijrah. Hal ini dilakukan dalam rangka menemani sang suami yakni responden II dalam melakukan misi dakwahnya. Dengan demikian, kedatangan beliau selain berbakti kepada sang suami juga untuk berdakwah.

d. Responden IV

Awal kedatangan responden IV ke Kotabaru adalah pada tahun 2003 bersama responden I dan tiga orang lainnya, dalam rangka safari Ramadhan. Persis dengan yang lainnya, kedatangan beliau berdasarkan permintaan dari masyarakat setempat. Pada kedatangan yang kedua kali di tahun 2005, beliau langsung memutuskan untuk hijrah. Dengan niat dan tujuan yang sama yakni melakukan dakwah, berjuang di jalan Allah untuk menyebarkan iman dan taqwa sesuai cita-cita Nahdhatul Wathan.

Berdasarkan hasil wawancara dengan para responden, sebelum memutuskan hijrah ke Kotabaru, mereka pernah melakukan misi dakwah ke berbagai wilayah di Indonesia. Seperti responden IV, melakukan safari Ramadhan ke Sulawesi pada tahun 2002, kemudian bersama responden I diutus ke salah satu pondok pesantren di Jawa Tengah pada tahun 2004 selama 4 bulan dalam rangka membantu menghidupkan pondok pesantren. Begitu juga dengan responden III, sebelum ke Kotabaru beliau melakukan misi dakwah ke Sulawesi pada tahun 2003 dalam rangka safari Ramadhan. Setelah berbagai macam pengalaman berdakwah ke wilayah-wilayah di Indonesia, pada tahun 2005 mereka memutuskan untuk hijrah dari kampung halaman yakni pulau Lombok ke Kotabaru dengan membawa mandat dari Masyaikh dan Pengurus Besar NW di Pancor untuk memperjuangkan visi-misi dan cita-cita NW di wilayah tersebut.

Dari pemaparan tadi, dapat diformulasikan bahwa setidaknya ada tiga bentuk keluarnya para abituren NW dari kampung halaman untuk melakukan misi dakwah. Pertama, melalui program safari Ramadhan, yakni sejumlah santri atau abituren dikirim ke berbagai wilayah baik di dalam maupun di luar pulau Lombok dengan membawa misi dakwah menyebarkan cita-cita dan pokok NW yakni iman dan taqwa. Hal inilah yang dilakukan oleh para abituren NW yang hijrah ke Kotabaru, sebelum memutuskan untuk hijrah, mereka datang sebagai tim safari Ramadhan.

Kedua, sebagai utusan langsung yang ditugaskan untuk membantu, membimbing dan membina ummat di wilayah tertentu. Sebagai contoh adalah seperti yang dilakukan oleh responden I dan responden IV yang diutus ke salah satu Ponpes di Jawa Tengah dalam rangka membantu menghidupkan pesantren tersebut.

Ketiga, adalah keluar dalam rangka hijrah yaitu secara fisik mereka pindah dari kampung halaman ke tempat yang baru dengan membawa mandat dari masyayikh dan pengurus besar NW untuk memperjuangkan visi-misi, cita-cita dan pokoq NW di tempat yang baru. Hijrah semacam inilah yang kemudian termasuk dalam makna hjirah di jalan Allah dan Rasul-Nya karena hijrahnya tersebut adalah untuk kebaikan sehingga insyâ'allâb bernilai ibadah. 
Hijrahnya para abituren NW ke berbagai wilayah itu secara umum berdasarkan amanat dari para masyayikh dan pengurus pusat NW, baik yang ditugaskan secara resmi dengan membawa surat tugas, maupun berdasarkan penugasan secara langsung tanpa membawa surat tugas. Adapun terkait dengan tempat tujuan hijrahnya, sebelum mereka memutuskan untuk hijrah ke tempat tersebut, telah terjadi komunikasi antara Pengurus Pusat NW dengan pihak dari tempat tujuan hijrahnya. Sebagaimana yang terjadi pada para abituren NW Lombok yang hijrah ke Kotabaru, diawali dengan program safari Ramadhan kemudian terjadi komunikasi lebih lanjut, dan akhirnya mereka diutus sebagai pejuang NW hijrah ke tempat tersebut.

Jika diamati lebih jauh, dapat diketahui bahwa hijrahnya para abituren NW tersebut juga memiliki keterkaitan dengan transmigrasi. Bukan berarti mereka yang melakukan transmigrasi, akan tetapi tempat tujuan hijrahnya tersebut banyak yang merupakan daerah transmigrasi. Hal ini dikarenakan sebagian dari para transmigran adalah orang Lombok yang notabenenya telah mengenal NW terlebih dahulu. Seperti yang dilakukan di Kotabaru, tempat tujuannya adalah desa-desa transmigrasi yang masih minim pembinaan kegamaannya. Dengan demikian, hijrah yang dilakukan oleh para abituren NW tersebut memiliki manfaat yang lebih dibandingkan jika mereka hijrah ke daerah yang telah maju.

\section{Kontribusi Hijrahnya Abituren Nahdhatul Wathan bagi Masyarakat Setempat}

Untuk mengetahui kontribusi hijrahnya para abituren NW, berikut diberikan gambaran mengenai kegiatan atau aktifitas masing-masing abituren yaitu: Responden I, berdomisili di Desa Subur Makmur Kecamatan Pulau Laut Barat Kabupaten Kotabaru. Saat ini beliau tercatat sebagai salah satu ustadz di Madrasah Tsanawiyah NW Desa Subur Makmur. Kegiatan sehari-hari lebih disibukkan dengan membina para santri karena beliau merupakan pimpinan Pondok Pesantren Nurun Nahdhatain. Selain mengajar, beliau juga aktif memberikan ceramah agama di desa tempat beliau tinggal dan sering diundang ke berbagai tempat sebagai penceramah dalam peringatan hari besar Islam, seperti Maulid Nabi, Isra' Mi'raj, Nuzul al-Qur'an, dan lain sebagainya.

Responden II, berdomisili di Desa Bandar Raya Kecamatan Pulau Laut Tanjung Selayar Kabupaten Kotabaru. Beliau salah satu ustadz yang paling sibuk karena aktif sebagai pengajar di dua sekolah yakni Madrasah Aliyah Lontar Pulau Laut Barat dan Madrasah Tsanawiyah NW yang berjarak 25-30 km dari tempat beliau tinggal. Selain itu, beliau juga aktif memberikan pengajian selaku pimpinan sebuah majelis ta'lim, menjadi imam, khotib, dan memberikan ceramah agama di berbagai tempat.

Responden III, berdomisili di Desa Bandar Raya Kecamatan Pulau Laut Tanjung Selayar Kabupaten Kotabaru. Sebagai isteri dari seorang ustadz, kegiatan sehari-hari disibukkan dengan menjadi seorang pengajar Taman Kanak-kanak di tempat beliau tinggal. Kemudian selaku lulusan Ma'had Darul Qur'an wal Hadits, beliau juga memberikan ceramah agama di pengajian khusus wanita.

Responden IV, berdomisili di Desa Subur Makmur Kecamatan Pulau Laut Barat Kabupaten Kotabaru. Aktifitas sehari-hari beliau lebih disibukkan di dunia pendidikan selaku kepala sekolah Madrasah Tsanawiyah NW Desa Subur Makmur dan aktif mengajar di sekolah tersebut. Beliau juga aktif menjadi imam dan khotib serta memberi pengajian di Desa, juga sering diundang sebagai penceramah pada peringatan hari besar Islam.

Selanjutnya, untuk mengetahui lebih jauh tentang kontribusi hijrahnya, berikut tanggapan masyarakat tentang kedatangan para abituren NW dan kontribusi mereka bagi masyarakat setempat. Informan I adalah salah satu tokoh masyarakat setempat yang menjabat sebagai Sekdes (Sekretaris 
Desa). Beliau memberikan komentar bahwa masyarakat sangat senang dengan kedatangan para abituren NW tersebut, mengingat pembinaan agama di daerah setempat terhitung masih minim sehingga kedatangan mereka sangat diharapkan. Masing-masing abituren memiliki kelebihan yang berbeda dalam artian ada yang memiliki kelebihan pada bidang pendidikan, seperti responden IV yang dipercaya untuk menjadi kepala sekolah. Kemudian responden I yang notabenenya seorang $\underline{b} a f i d z$, alQur'ân dan memiliki kelebihan pada bidang dakwah sehingga beliau dipercaya memimpin pondok pesantren. $^{34}$

Informan II adalah seorang guru muda di Madrasah Tsanawiyah NW. Beliau memberikan komentar bahwa masyarakat mayoritas merasa senang dengan kedatangan para abituren NW ke tempat mereka. Besar harapan masyarakat kepada mereka untuk membawa perubahan yang lebih baik bagi masyarakat setempat, terutama perubahan yang lebih baik pada aspek keagamaan. Kemudian terkait dengan kontribusi yang mereka berikan, para abituren yang datang memiliki karakter yang berbeda, seperti responden IV yang lebih fokus pada pendidikan formal, responden I lebih fokus pada keagamaan, responden III dan IV yang mencakup keduanya. ${ }^{35}$

Informan III adalah tokoh masyarakat yang menjabat sebagai ketua RT di Desa Subur Makmur. Beliau memberikan komentar bahwa masyarakat menerima dengan baik bahkan sangat membutuhkan kedatangan para abituren NW ke tempat mereka. Pembangunan pada bidang pendidikan sangat terbantu, terlebih pada bidang agama, mereka menjadi tumpuan masyarakat untuk bertanya tentang masalah agama. ${ }^{36}$

Informan IV adalah seorang tokoh agama dan merupakan ketua Yayasan al-Majidiyah yang sekaligus tokoh pendiri Pondok Pesantren Nurun Nahdhatain Nahdhatul Wathan Kotabaru. Beliau memberikan komentar bahwa pada dasarnya masyarakat menerima dengan senang hati atas kedatangan para abituren NW ke tempat mereka, mengingat pada awalnya memang masyarakat lah yang meminta untuk mendatangkan ustadz-ustadz tersebut.

Pada dasarnya, kontribusi mereka bagi masyarakat setempat menjadi sangat signifikan, karena dengan adanya para abituren NW yang datang sangat membantu pembinaan keagamaan di daerah tersebut. Tidak terkecuali pada bidang pendidikan, mereka memiliki peran penting atas keberlangsungan TPQ, diniyah, tsanawiyah, dan pondok pesantren di daerah tersebut. ${ }^{37}$

Di Kotabaru khususnya, wilayah yang menjadi tujuan hijrah mereka adalah daerah transmigrasi yang dihuni oleh berbagai macam suku dan agama. Tingkat pendidikan dan keagamaan di daerah tersebut pada mulanya terbilang cukup rendah, akan tetapi dengan kehadiran para abituren NW di tempat tersebut, kekurangan-kekurangan tersebut dapat teratasi. Sebelum datangnya para abituren NW Lombok, mereka kesulitan menyekolahkan anak-anak mereka yang lulusan SD karena sekolah menengah pertama (SMP) yang terdekat berjarak belasan kilometer dari tempat tersebut. Setelah para abituren datang, dibangunlah madrasah tsanawiyah dan mereka mengajar di sekolah tersebut sehingga anak-anak lulusan SD dapat bersekolah di MTs Nurun Nahdhatain. Ditambah lagi dengan adanya pondok pesantren yang dibina oleh para abituren NW, para santri banyak mendapatkan ilmu agama dan dibimbing menjadi hafizh Quran. Bahkan santri dari pondok pesantren tersebut sering mewakili Kotabaru pada ajang MTQ di tingkat Provinsi khususnya bidang tahfizh.

Selanjutnya pada bidang sosial, kontribusi para abituren NW yang sangat tampak adalah bagi generasi muda, yang pada mulanya generasi muda tenggelam dalam kenakalan remaja, perlahan berubah menjadi pribadi yang lebih baik berkat ilmu agama yang didapat. Hal ini juga sangat erat

${ }^{34}$ Sekretaris Desa Subur Makmur, Wawancara Pribadi, Kotabaru, 30 April 2016.

${ }^{35}$ Guru MTs Nurun Nahdhatain, Wawancara Pribadi, Kotabaru, 1 Mei 2016.

36Ketua RT 02 Desa Subur Makmur, Wawancara Pribadi, Kotabaru, 01 Mei 2016.

${ }^{37}$ Ketua Yayasan al-Majidiyah Pondok Pesantren Nurun Nahdhatain Nahdhatul Wathan, Wawancara Pribadi, Kotabaru, 03 Mei 2016. 
kaitannya dengan kontribusi mereka dalam berdakwah, dengan adanya pengajian, ceramah agama, dan yang menjadi tradisi adalah pembacaan hizib Nahdhatul Wathan, sehingga dengan sendirinya tercipta kerukunan antar sesama, semangat tolong menolong, suasana kondusif dan religius.

Melihat tradisi hijrah yang dilakukan oleh para abituren NW Lombok seperti yang dikemukakan tadi, tradisi tersebut merupakan fenomena sosial Muslim terkait teks al-Qur'an dan Hadis yang berusaha meneladani Nabi Saw. Pada praktiknya, ketika hijrah dari Makkah ke Madinah, hal pertama yang dilakukan Nabi Saw. adalah membangun masjid. ${ }^{38}$ Masjid memiliki multifungsi antara lain sebagai tempat melaksanakan ibadah shalat. Selain itu fungsi masjid sebagai pusat kegiatan pendidikan dan pengajaran keagamaan, tempat pengadilan berbagai perkara yang muncul di masyarakat, musyawarah dan lain sebagainya. Lebih dari itu, bangunan masjid bukan saja sebagai tonggak berdirinya masyarakat Islam, tetapi juga awal pembangunan kota.

Hal yang sedikit berbeda dilakukan oleh para abituren NW Lombok di Kotabaru, yaitu mereka membangun madrasah sebagai langkah pertama. Mengingat latar belakang hijrah yang dilakukan oleh Nabi dan para abituren NW berbeda baik dari setting sosial, poitik, ekonomi, keagamaan, dan lain sebagainya. Oleh sebab itu, sudah seyogyanya perbedaan tersebut terjadi. Meski demikian, hijrah yang dilakukan para abituren NW tetap dalam upaya meneladani Nabi dalam aspek ruang dan waktu yang berbeda.

Praktik meneladani Nabi dalam hal tertentu tidak mesti harus sama persis seperti apa yang dilakukan Nabi. Sebagai contoh Nabi dan para Sahabat menggunakan unta sebagai kendaraan, maka seiring dengan perkembangan teknologi dan ilmu pengetahuan, hal itu tidak digunakan lagi, zaman sekarang lebih efektif jika menggunakan kendaraan bertenaga mesin. Dengan demikian, upaya meneladani Nabi dapat disesuaikan dengan zamannya. Adapun kesamaan antara yang dilakukan Nabi dan para abituren NW yang hijrah ke Kotabaru adalah upaya dalam membangun masyarakat ke arah yang lebih baik. Hal ini sebagai praktik nyata dalam meneladani Nabi Muhammad Saw.

\section{Penutup}

Berdasarkan uraian-uraian sebelumya, dapat disimpulkan bahwa para abituren NW Lombok memahami hadis tidak secara tekstual dalam artian tidak hanya berdasarkan bunyi teks, akan tetapi mereka juga mempertimbangkan konteks hadis. Seperti hadis hijrah di jallan Alah dan Rasul-Nya diartikan dengan hijrah kepada kebaikan yakni melakukan hal-hal yang di ridhai oleh Allah dan sesuai dengan tuntunan Rasul-Nya. Kemudian hadis tidak ada hijrah setelah fath Makkah diartikan dengan tidak adanya hijrah seperti yang dilakukan oleh Nabi dan para Sahabat sebelum fath Makkah karena gejolak yang terjadi pada saat itu, akan tetapi hijrah setelah itu adalah dengan jihad dan niat.

Tradisi hijrah di kalangan abituren Nahdhatul Wathan telah berlangsung puluhan tahun sejak berdirinya organisasi tersebut. Praktek hijrah yang dilakukan berdasarkan dalil al-Qur'an yakni Surah al-Jumu'ah ayat 10, al-Baqarah ayat 218, dan al-'Ashr ayat 3, dan berdasarkan hadis hijrah di jalan Allah dan Rasul-Nya yang diriwayatkan oleh Al-Bukhari. Hijrah yang dilakukan ke Kotabaru Kalimantan Selatan diawali dari program Safari Ramadhan kemudian memustuskan hijrah ke tempat tersebut dengan membawa misi dahwah memperjuangkan visi-misi NW yakni menyebarkan iman dan taqwa.

${ }^{38}$ Shafiyyur rahman al-Mubarakfury, Sirab Nabawiyah, terj. Kathur Suhardi (Jakarta: Pustaka al-Kautsar, 1997), 
Hijrah yang dilakukan tersebut merupakan aktualisasi dari proses meneladani Rasulullah Saw. Hijrah yang dilakukan Nabi adalah untuk dakwah yakni mengajak manusia untuk mengesakan Allah dan memeluk agama Islam. Begitu pula hijrah yang dilakukan para abituren NW Lombok ke Kotabaru dengan membawa misi dakwah melalui dunia pendidikan khususnya, sosial, dan dakwah Islamiyah. Teladan Nabi yang dalam Islam disebut Sunnah yang kemudian dipraktikkan oleh para abituren NW inilah yang disebut sebagai living sunnah []

\section{DAFTAR PUSTAKA}

Aḥmad, Ibn Muhammad Ibn ㅂanbal, al Musnad, Riyadh: Maktabah at-Turâts al-Islâmî, 1994.

Al-'Asqalânî, Syihabudin Abû al-Fadhl Aḥmad Ibn 'Alî Ibn Muhammad Ibn Aḥmad Ibn Hajar, Syara $\underline{h}$ Shahㅡㄴ al-Bukhari, Terj. Gazirah Abdi Ummah, Jakarta: Pustaka Azzam, 2002.

Azzam, Abdullah, Hijrah dan I'dad, terj. Abdurrahman, Solo: Pustaka al-Alaq, 2001

Badan Perencanaan Pembangunan daerah Kotabaru, "Geografis Kotabaru", dalam http:// www.bappeda-kotabaru.info/umum/80/, diakses pada 6 Mei 2016.

Badan Pusat Statistik, dalam http://kalsel.bps.go.id/linkTableDinamis/view/id/813, diakses pada 6 Mei 2016.

Al-Bukhari, Muhammad Ibn Ismâ'îl Abû 'Abdullâh, Shaḩîh al-Bukhari, T.tp: Dâr Thauq al-Najâh, $1422 \mathrm{H}$

Dâwud, Abû Sulaimân Ibn Asy’ats as-Sijistâni, Sunan Abû Dâwud, Suriah: Dâr al-Hadîts, t.th.

Habib, Muslihan dan Thaharuddin, Nilai-nilai Monumental dalam Semboyan NW, Jakarta: Penerbit Pondok Pesantren NW, 2013.

Info Kalsel, "Kabupaten Kotabaru" dalam http://infokalsel.blogspot.co.id/2011/04/ kabupatenkotabaru.html, diakses 6 Mei 2016.

Al-Khatib Muhammad 'Abdullah, Makna Hijrah Dulu dan Sekarang, terj. Abdul Mu'in HS dan Misbahul Huda, Jakarta: Gema Insani Press, 2002.

Mâjah, Abû 'Abdullâh Ibn Yazid Ibn al-Qazwinî, Sunan Ibn Mâjah, t.tp: Dâr Ihya al-Kutb al'Arabiyyah, t.th.

Masnun, Tuan Guru K.H. Zainuddin Abdul Majid: Gagasan dan Gerakan Pembaharuan Islam di Nusa Tenggara Barat, Jakarta: Pustaka al-Miqdad, 2007.

Al-Mubarakfury, Shafiyyur rahman, Sirah Nabawiya, terj. Kathur Suhardi, Jakarta: Pustaka al-Kautsar, 1997.

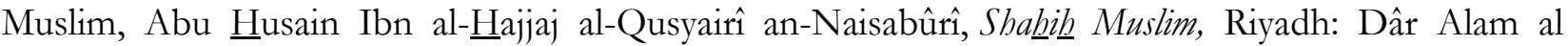
Kutub, 1996.

Al-Nasâ'î, 'Abdurrahman Aḥmad Ibn Syua'ib, Sunan an-Nasâ'î, Beirut: Dâr al-Kutub al-'Tlmiah, 1991.

Al-Tirmîdzî, Abû 'Isa Muhammad Ibn 'Isa Ibn Saurah, Sunan at-Tirmîdẓ̌̂, Beirut: Dâr al-Fikr, 1994.

Syamsudin, Sahiron (ed), Metodologi Penelitian Living Qur'an dan Hadis, Yogyakarta: Teras, 2007. 